\title{
Frustration Factor in Group Collaborative Learning Experiences
}

\author{
Lazarus Ndiku Makewa*, Dorcas Gitonga, Baraka Ngussa, Samwel Njoroge, Joshua Kuboja \\ School of Education, Department of Educational Administration, Curriculum and Teaching, University of Eastern Africa, Baraton, P.O. \\ Box 2500 Eldoret 30100, Kenya \\ *Corresponding author: ndikul@gmail.com
}

Received September 23, 2014; Revised October 09, 2014; Accepted December 08, 2014

\begin{abstract}
This study was carried out in the University of Eastern Africa, Baraton, Kenya. It sought to find out students' frustration level after group learning experiences, how often they went through these experiences, how frustration affected their Bachelor of Education Program, how BED with its group collaborative learning methodology met their expectations, if they were getting quality training and finally if they would take part in the future in another course requiring group collaborative learning. A larger percentage of students stated that they were frustrated as they went through collaborative learning. However, they did not feel that frustration as factor has any effect on their Bachelor of Education program. Collaborative learning as a set of instructional strategies, when used properly, can help learners to meet specific learning and social interaction objectives in structured groups. It can also promote social interaction to facilitate knowledge construction. Further, if students are well prepared to work in small groups and if the groups are well organized, students' collaboration can increase students' achievement more than traditional methods of learning. It is therefore recommended that in the course of the lesson, teachers set time for group work to motivate the learners, not only interacting with the content, but also with the group members.
\end{abstract}

Keywords: students, attitudes, group collaborative, learning experiences, frustrations

Cite This Article: Lazarus Ndiku Makewa, Dorcas Gitonga, Baraka Ngussa, Samwel Njoroge, and Joshua Kuboja, "Frustration Factor in Group Collaborative Learning Experiences.” American Journal of Educational Research, vol. 2, no. 11A (2014): 16-22. doi: 10.12691/education-2-11A-3.

\section{Introduction}

The concept of collaborative learning, the grouping and pairing of students for the purpose of achieving an academic goal has been widely researched and advocated throughout the professional literature. Chambers Dictionary defines collaboration as to work in association with. It is the opposite of one working in isolation. The idea of collaborative learning is supported by Atkinson (1964) in Gillies, Ashman and Terwel (2007) who once said, "Achievement is a we thing, not a me thing, always the product of many heads and hands."

Collaborative learning is described by Barkley, Cross and Major (2005) as learning activities expressly designed for and carried out through pairs or small interactive groups, working with one another or others, in pairs or small groups to achieve shared learning goals. It also means group working together rather than learning by working alone. It is the instructional use of the small groups so that students work together to maximize their own and each other's learning. Another term that can be used interchangeably with collaborative learning is cooperative learning though the two are not the same in operation.

According to Moore (2009), cooperative learning is more than simply putting students in groups but it requires that students work together in mixed-ability, gender and ethnicity groups in accomplishing a set of tasks. The percentage of high, middle or lower learners in each group should represent the appropriate population of each group in the whole class.

Kauchak and Eggen (2008) consider collaborative learning as a set of instructional strategies that is used to help learners meet specific learning and social interaction objectives in structured groups. Barkley, Cross and Major (2005, p. 4) give three features for effective collaborative learning:

- Intentional Design: The teacher must intentionally and not by chance group learners in a systematic way.

- Co-laboring: All participants in a group must engage actively in working together toward the stated objective.

- Meaningful learning: As students work together on collaborative assignments, they must increase their knowledge or deepen their understanding of the topic under discussion.

\subsection{Leadership and Size of Small Collaborative Groups}

Groups cannot succeed without leadership. Bergh and Theron (2006) support this when they argue that a working group is an unorganized mob. It must have a formal leader who can be identified with a varied range of titles such as manager, supervisor, foreman, project leader 
or head. They also maintain that this leader plays an important role in the group's success, and conclude that for high satisfaction in the group participative leadership is more effective than autocratic leadership. This idea suggests that a leader in class discussion groups should not dominate group activities but should give opportunity for each group member to give out their views and contributions. Furthermore, the leadership in the groups should be rotational so that many members in the group will have opportunity to develop leadership skills.

Significance of well sized groups for collaborative learning is indicated by Sharan et al., (1984); Sharan and Shachar, (1988) in Slavin (2009, p. 223) who have it that if students are well prepared to work in small groups and if the groups are well organized, students collaboration can increase students achievement more than traditional methods of learning. Johnson and Johnson in Slavin (2009, p. 223) further maintain that small group discussions have greater effects on students achievement if students are encouraged to engage in controversy rather than to seek a consensus. Gagne, Wager, Golas and Keller, 2005, p. 290) state that "a great deal of instruction is done with learners assembled in groups of various sizes.”

The size of collaborative learning groups varies, depending on the task to be accomplished, but the common group size tends to be four (Moore, 2009). Slavin (2009, p. 222) argues that "in small group discussion, students should work in four-to-six members to discuss a particular topic." In addition to that Slavin gives the following characterizing guidelines for effective group discussion:

- Small group discussion must follow the presentation of information through teacher-directed lesson, books or videos or following an opportunity for students to find information for themselves in the library or on the internet.

- Students need to pull desks together to talk to and hear one another more easily.

- Each group should have a leader.

- Leaders should be responsible, well organized and should not always be the highest -achieving students.

- Groups may discuss the same topic or each may discuss a different subtopic of a large topic that the whole class is studying.

- The teacher should give each group a series of questions to answer on the topic under discussion.

- The leader's role in each discussion group is to make sure that the group stays on the topic and questions assigned to it, and to ensure all group members participate.

- A group recorder may be appointed to write down the group's ideas.

- At the end of the discussion, the group has to prepare a report on their activities or conclusion to present to the rest of the class members.

\subsection{Unity and Dynamics in Small Groups}

Small groups are formed by people of different personalities, backgrounds, attitudes, culture and behavior. Amid all these dynamic differences, the target is to ensure togetherness, which can be brought by common interests. Togetherness is an important ingredient for the success of collaborative learning experiences.
Rue and Byars (1993) support this when they argue that once groups have been formed, they seem to take on a life of their own and over time, they develop certain characteristics and a set way of doing things. This is what is referred to by Bergh and Theron (2006) as group normsstandard of behavior that are shared by the group members and that provide guidance about what to do or not to do in certain circumstances. They further argue that when agreed and accepted by the group, norms act as means of influencing the behavior of group members with a minimum of external controls.

In the context of collaborative learning groups, a teacher needs to encourage every group to set a varied range of norms which do not contradict with school culture. This is also supported by Moore (2009, p. 203) who argues that team members should be allowed a great deal of freedom as they decide how to deal with the assigned task.

Rue and Byars (1993) and Fincham and Rhodes (2005) also argue that group norms are important sources of unity in the groups. They refer to group norm as an understanding among group members concerning how members should behave.

\subsection{Motivation in Group Collaborative Learning}

Group works cannot be effective without motivation. The teacher is the chief supervisor of class groups. He is one of the sources for motivation in the group. He needs to encourage and motivate each member of the groups to actively participate in group activities. Rue and Byars (1993) brings to view roles of supervisors of groups at work. He argues that the supervisor needs to consciously encourage members to participate in group activities, interact well with group members and have high performance goals. It is therefore the responsibility of the teacher to build these qualities among group members.

Besides, group members' individual accountability and personal responsibility are important ingredients for motivation (Moore, 2009 and Gillies, Ashman and Terwel (2007). This is supported by Moore (2009, p. 203) who has it that "individual accountability is an essential characteristic of all cooperative learning. He suggests that accountability means that the success of the group is based on the individual learning of each team member. Accountability occurs when each student in the group is held responsible for the required learning goals."

This is supported by Gillies et al. (2007, p. 22) who maintain that positive interdependence creates responsibility forces that increase group members' feeling of responsibility and accountability for completing one's share of the work and facilitating the work of other group members. They cite Matsui et al. (1987) who argues that when person's performance affects the outcomes of collaborators, the person feels responsible for their welfare as well as his own. Thus, the shared responsibility created by positive interdependence adds the concept of "ought to" to group members' motivation. They conclude that "such feelings of responsibility increase a person's motivation to perform well.”

\subsection{Frustration in Collaborative Learning}

In learning contexts, students do report experiencing a range of emotions, and frustration is one of the negative 
emotions they deal with (Do \& Schallert, 2004; Pekrun, Goetz, Titz, \& Perry, 2002). Despite the advantages reported in literature about collaborative learning methodologies in terms of social and psychological benefits (Panitz, 2001; Roberts, 2005), students engaged in collaborative learning activities can feel a high level of frustration.

According to Mandler (1975), frustration can be defined as a negative emotion aroused upon encountering an obstacle in the achievement of a task, goal, or expectation, or in satisfying one's needs. Frustration is a concept related to goal attainment (Lazar, Jones, Bessiere, Ceaparu, \& Shneiderman, 2004). People may feel frustrated when they are deprived of their expectations or are not able to complete their plans (Handa, 2003; Mandler, 1975). Frustration is one of the most commonly mentioned negative emotions associated with group learning. Recent studies have described emotional and motivational experiences students encountered during group learning projects (Hyvönen, 2001), which can also cause negative effects (Artino \& Stephens, 2007; Artino, 2008; Hickey, Moore, \& Pellegrino, 2001; Järvenoja \& Järvelä, 2005; Sierpinska, Bobos, \& Knipping, 2008). Some collaborative learning environments may interfere with students' willingness to engage in the project. They may also experience stress and frustration in collaborating with people they do not know well (Curtis \& Lawson, 2001).

Student frustration can be caused by internal or external factors (Bessiere, Newhagen, Robinson, \& Shneiderman, 2006), and it can adversely affect a student's learning experiences. The consequences of student frustration (Borges, 2005) can generate a load that has to be borne by all the agents involved in the learning experiences: students, teachers, and institutions. Finally, disillusionment and frustration can lead students to abandon their studies and leave the institution (Conrad, 2002).

\subsection{Theoretical Frameworks}

\subsubsection{Collaborative Groups}

According to Bruffee (1999), the purpose of collaborative groups is to achieve consensus and shared classroom authority. Newcomb (1962) maintains that the consensusbuilding process places knowledge construction within the small groups, among peers, rather than between the learners and the teacher. Bringing the group members' different points of view together into a consensus or synthesis of knowledge involves considerable group discussion.

Group discussions should encourage individuals to coordinate different points of view, which in turn enhances reasoning and higher order thinking skills that promote shared knowledge construction (McKnight, 2000). During the consensus process, learners are more likely to submit their previous unshared beliefs and opinions to the group for consideration. The consensus process, therefore, provides space for meaning making (Bruffee, 1999) and self-reflection (Schon, 1990). Through iterative cycles of discussion and reflection (Schon, 1990), learners integrate their individual perspectives with relevant theory and research to promote changes in beliefs and to construct knowledge.
Yet, learners in collaborative groups may fail to attain problem-solving skills (Oliver \& Omari, 2001). Furthermore, the challenges learners face with collaborative groups may reinforce the learners' traditional beliefs rather than shift their thinking to the new paradigm (Clarebout \& Elsen, 2001). Collaborative group members are further challenged by the previous educational socialization that promotes distrust and competition among learners and reliance upon the teacher for knowledge that learners bring into the online environment (McConnell, 2002).

Although the above challenges provide an explanation for many of the issues collaborative group members face, they minimize the ways in which the emotional issues may mediate learning within these contexts. An examination of the group dynamics process can further clarify the issues the learners may face as they work within collaborative groups.

\subsubsection{Group Dynamics}

There is scant research to enable an understanding of the group dynamics within collaborative groups. This section, therefore, relies heavily on the face-to-face literature. Group dynamics theorists (see, e.g., Bennis \& Shepard, 1956; Bion, 1961; Gibbard, 1974; K. Smith \& Berg, 1987) maintain that the central issue for individuals when they join a group is the unconscious tension generated by the conflicting fears of de-individualization (the learner's identity is obliterated or totally consumed into the group identity) at one extreme and of estrangement from the group at the other extreme. Unger (1984) explains that all humans crave the possibility for self-expression that they gain in association with one another. Yet, the work required to reach consensus threatens individual voice within a group voice (Dirkx \& Smith, 2004; R. Smith, 2003). This tension is extremely emotionally laden, usually unconscious, and creates strong, unbearable love/hate feelings toward the group situation (Dirkx \& Smith, 2004; Wells, 1995). Group members, therefore, tend to psychologically or socially withdraw from the group to eliminate the tension.

Yet, to achieve individuation (a personal and distinct identity within the group), group members must release aspects of their individuality (subjectivity) to connect (intersubjectivity) with one another to share and empathize with one another's common fears (Smith \& Berg, 1987) of estrangement or obliteration. Moving from subjectivity to intersubjectivity within groups is inhibited by the learners' inability or unwillingness to release the tight hold on their previous schooling socialization (competitiveness and mistrust) with its embedded subjective and individualistic understandings of teaching and learning (Dirkx \& Smith, 2004). The collaborative group work runs the risk of minimizing or even ignoring individual identity or subjectivity (Dirkx \& Smith, 2004). A continued collegiality also threatens learners' abilities to maintain their sense of individual voice within the collaborative group. The added stress of consensus, the dynamics of group development and the communication challenges within the learning environment serve to add to the participants' ambivalence about group work (Dirkx \& Smith, 2004; Ragoonaden \& Bordeleau, 2000; R. Smith, 2003). 
Group members also make quick judgments about their fellow group members' ability to contribute to the group in ways that mirror societal hierarchical structures (Cheng, Chae, \& Gunn, 1998; Wells, 1995; Wheelan, 1994; Winter, 1974). Wheelan (1994) contends that during early group developmental stages, group members unconsciously assign roles based on the limited information they have about one another. Once the roles are assigned, it is difficult to change them because the group is unaware that it assigned the roles. Individual groups remain in the first stage of group development longer than face-to-face groups (McConnell, 2002, Trujillo, 1997). In extrapolation, the group members may remain locked into roles that mirror societal hierarchical structures.

\section{Method}

This study employed a descriptive survey design. Students from the school of Education were the target population. Stratification sampling technique was used to get the specific students from each year. The undergraduate Education students in first, second, third and fourth years formed the strata for this study. For each of the strata, cards with 'Yes' and 'No' were generated and put in baskets. Each basket had fifteen cards with 'Yes' and the rest of the Cards were 'No'. To draw a representative sample of students, the researchers made use of simple random sampling procedure in that, those who picked 'Yes' filled the questionnaire which was the only means of data collection. In this way, each student had equal chance of being selected. The researchers came up with 60 students as representative sample, which is $33 \%$ of all Bachelors of Education students.

The researchers designed self-administered questionnaires that were given to the sampled students. The Questionnaires were divided into two major sections. Section 1 solicited demographic information of the respondents and section 2 solicited information on student's frustration in collaborative learning.

In order to maintain Content Validity, the researchers consulted colleagues in the Department of Educational Administration, Curriculum and Teaching of University of Eastern Africa, Baraton, to assess the degree to which the instruments suited specific needs, covered the intended content and was in harmony with the questions that guided the study. The feedback was used to make appropriate corrections and adjustments.

For further validation and acceptable reliability of the instruments, the researchers carried out pilot-testing from Bachelor of Education students at the University of Arusha Musoma Center. This was done in order to determine whether the items in the instruments were clear to the respondents. Items that were found ambiguous or unclear were either eliminated or restructured to improve the validity of the instrument. The researchers used Cronbach's Alpha to ensure internal consistency of the instruments and to eliminate chance error due to differing test conditions as can be found in the test-retest technique. Using $17^{\text {th }}$ version of the Statistical Package for Social Sciences (SPSS), the instrument yielded a reliability index of 0.76 which is acceptable in education and Social Science studies.

\section{Results and Discussion}

This study sought to find out students' frustration level after group learning experiences, how often they went through these experiences, how frustration affected their Bachelor of Education Program, how BED with its group collaborative learning methodology met their expectations, if they were getting quality training and finally if they would take part in the future in another course requiring group collaborative learning. Students' responses are shown in Table 1 to Table 6.

Table 1. Level of frustrated after group collaborative learning experiences

\begin{tabular}{llllll}
\hline & & Frequency & Percent & Valid Percent & Cumulative Percent \\
\hline \multirow{4}{*}{ Valid } & Frustrated & 18 & 35.3 & 35.3 & 35.3 \\
& Not frustrated at all & 12 & 23.5 & 23.5 & 58.8 \\
& A bit frustrated & 11 & 21.6 & 21.6 & 80.4 \\
& Very frustrated & 10 & 19.6 & 19.6 & 100.0 \\
& Total & 51 & 100.0 & 100.0 & \\
\hline
\end{tabular}

Respondents were asked to state their level of seldom will one find a group that is perfect in all aspects frustration after group collaborative learning experiences. Table 1 gives details of the analysis.

Table 1 shows that majority (54.9\%) of respondents were frustrated after group collaborative learning. Particularly, the table indicates that $35.3 \%$ were frustrated while $19.6 \%$ were very frustrated. This is so because of keeping time, sticking to goals of the collaborative learning and coming to consensus on certain points. This therefore informs the reason for feeling frustrated. On top of that, respondents were asked how often they went through these frustration experiences. The results are as shown on Table 2.

Table 2. Frequency of going through these frustrating experiences

\begin{tabular}{llllll}
\hline & & Frequency & Percent & Valid Percent & Cumulative Percent \\
\hline \multirow{4}{*}{ Valid } & Rarely & 16 & 31.4 & 31.4 & 31.4 \\
& Often & 15 & 29.4 & 29.4 & 60.8 \\
& Occasionally & 10 & 19.6 & 19.6 & 80.4 \\
& Very often & 10 & 19.6 & 19.6 & 100.0 \\
& Total & 51 & 100.0 & 100.0 & \\
\hline
\end{tabular}


With exception of $31.4 \%$ of the respondents who observed that rarely do they have frustrating experiences, majority were occasionally, often or very often frustrated. This suggests that collaborative learning experiences among the respondents are frustrating in nature.

Whether frustration affected Bachelor of Education program, data shows that only $43 \%$ of the participants indicated that frustration affected BED program while $56.6 \%$ indicated that frustration did not have any effect or had just a little frustration. This shows that most of students have a good attitude towards collaborative learning and they feel that frustration has little or no effect on the Bachelor of Education program.

Table 3. How frustration affected BED program

\begin{tabular}{|c|c|c|c|c|c|}
\hline & & Frequency & Percent & Valid Percent & Cumulative Percent \\
\hline & A little & 18 & 35.3 & 35.3 & 35.3 \\
\hline & Very much & 12 & 23.5 & 23.5 & 58.8 \\
\hline Valid & Nothing & 11 & 21.6 & 21.6 & 80.4 \\
\hline & Much & 10 & 19.6 & 19.6 & 100.0 \\
\hline & Total & 51 & 100.0 & 100.0 & \\
\hline
\end{tabular}

Table 4. If BED with its group collaborative learning methodology meets expectations

\begin{tabular}{llllll}
\hline & & Frequency & Percent & Valid Percent & Cumulative Percent \\
\hline \multirow{4}{*}{ Valid } & Strongly agree & 26 & 51.0 & 51.0 & 51.0 \\
& Tend to agree & 9 & 17.6 & 17.6 & 68.6 \\
& Strongly disagree & 8 & 15.7 & 15.7 & 84.3 \\
& Tend to disagree & 8 & 15.7 & 15.7 & 100.0 \\
& Total & 51 & 100.0 & 100.0 & \\
\hline
\end{tabular}

In regard to whether collaborative learning meets students' expectations, Table 4 shows that majority (68.6\%) of the respondents showed agreement. It can therefore be inferred that the students have a positive attitude towards collaborative learning because they strongly agree that it meets their expectations, hence it is helpful to them.

Table 5. Rating the quality of training you are getting

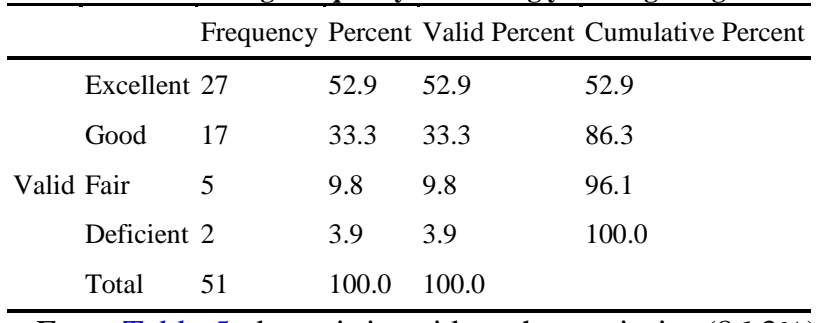

From Table 5 above it is evident that majority (86.3\%) of the respondents rated the quality of their training as excellent or good. This means that the students have a positive attitude towards collaborative learning. It can also be inferred to mean that most of the learners see the benefits which accrue from collaborative learning as helpful like sharing, co-operation and learning of leadership skills.

Table 6. As a result of your experience in this BED, would you take part in the future in another course requiring group collaborative learning?

\begin{tabular}{|c|c|c|c|c|}
\hline & Frequency & Percen & t Valid Percent & Cumulative Percent \\
\hline Surely yes & 30 & 58.8 & 58.8 & 58.8 \\
\hline Fairly yes & 14 & 27.5 & 27.5 & 86.3 \\
\hline Valid Fairly not & 5 & 9.8 & 9.8 & 96.1 \\
\hline Surely not & 2 & 3.9 & 3.9 & 100.0 \\
\hline Total & 51 & 100.0 & 100.0 & \\
\hline
\end{tabular}

This section intended to find how, as a result of experience in Bachelor of Education program, students would take part in the future in another course requiring group collaborative learning. Table 6 shows that majority (86.3\%) of the respondents accepted that as a result of their experiences they would take part in the future in another course requiring group collaborative learning. This is a positive observation which shows that collaborative learning has had a positive effect on the learners' school life and therefore given another opportunity they would confidently go for collaborative learning.

\section{Conclusions and Recommendations}

This study sought to find out students' frustration level after group learning experiences, how often they went through these experiences, how frustration affected their Bachelor of Education Program, how BED with its group collaborative learning methodology met their expectations, if they were getting quality training and finally if they would take part in the future in another course requiring group collaborative learning. A larger percentage of students stated that they were frustrated as they went through collaborative learning. Majority of them were occasionally, often or very often frustrated suggesting that collaborative learning experiences among the respondents are frustrating in nature. Most of students have a good attitude towards collaborative learning and they feel that frustration has little or no effect on the Bachelor of Education program.

A lot of problems arise from students' attitudes to learning and previous experience. Students who expect to be able to study independently and at their own pace are likely to be frustrated when forced to collaborate with students with different priorities and study habits. Having to work with others can be seen as an unwelcome distraction.

Getting everyone in the group to agree on commitment levels and ensuring that all make equal contributions can involve lengthy discussions, reminders and irritation. Often the lion's share of the burden is taken by one or two group members and others make only marginal contributions. This is especially unfair when the assessment is at group level since the teacher cannot see who contributed what. The main problem this study lifts is that many students are unprepared for collaborative learning in whatever form it may take and that guidance and coaching is required before the course starts. One of the main lessons learnt from taking part in any type of training is the ability to work in teams and all the negotiation skills that entails. 
In this study therefore, we observe that the students' main source of self-declared frustration is the teammates' commitment imbalance. Preparing the learner for collaboration through instruction and development of the social and group skills necessary to work effectively in a group will have a positive effect upon the collaborative experience. Further work is needed to understand how the instructor's role, group composition and grading policies might also influence the group's progress toward individuation and the unsafe spaces that are created during the process. We might suggest the aim of such facilitation is to enable group members to feel familiar with being lost, and to appreciate its potentially educative value.

\section{References}

[1] Adolphus, T; Alamina, A. and Aderonmu, A (2013). The Effects of Collaborative Learning.

[2] Allen, I. E., \& Seaman, J. (2007). Online nation: Five years of growth in online learning. Needham, MA: Sloan Consortium.

[3] Artino, A. R. (2008, March). Understanding satisfaction and continuing motivation in an online course: An extension of social cognitive, control-value theory. Paper presented at the annual meeting of the American Educational Research Association, New York, NY. Retrieved

fromhttp://www.sp.uconn.edu/ aja05001/comps/documents/AER A_2008_SEM_Artino_FINAL.pdf.

[4] Artino, A. R., \& Stephens, J. M. (2007, October). Bored and frustrated with online learning? Understanding achievement emotions from a social cognitive, control-value perspective. Poster session presented at the annual meeting of the Northeastern Educational Research Association, Rocky Hill, CT. Retrieved from http://www.sp.uconn.edu/ aja05001/comps/documents/NERA07_AchEmotions_Artino\%2BStephens.pdf.

[5] Barkley, E. F., Cross, K. P \& Major, C. H (2005). Collaborative learning techniques. United.

[6] Barron, B. (2003). When smart groups fail. The Journal of the Learning Sciences, 12 (3), 307-359.

[7] Bennis, W. G., \& Shepard, H. A. (1956). A theory of group development. Human Relations, 9, 415-457.

[8] Bergh, Z \& Theron, A (editors). Psychology in the work context. Cape Town: Oxford University.

[9] Bessiere, K., Newhagen, J. E., Robinson, J. P., \& Shneiderman, B. (2006). A model for computer frustration: The role of instrumental and dispositional factors on incident, session, and post-session frustration and mood. Computers in Human Behavior, 22 (6), 941961.

[10] Bion, W. R. (1961). Experiences in groups and other papers. New York: Basic Books.

[11] Borges, F. (2005). La frustració de l'estudiant en línia. Causes i accions preventives. Digithum [online article]. UOC. Núm. 7. Retrieved from http://www.uoc.edu/digithum/7/dt/cat/borges.pdf.

[12] Brownstein, B (2001). Collaboration: "The foundation of learning in the future," Education.

[13] Bruning, R. H; Schraw, G. J; Norby, M.M \& Ronning, R. R (2004). Cognitive psychology and instruction $\left(4^{\text {th }}\right.$ ed) upper Saddle River, NJ: Pearson Education.

[14] Bruffee, K. A. (1999). Collaborative learning: Higher education, interdependence, and the authority of knowledge (2nd ed.). Baltimore: John Hopkins University Press.

[15] Chambers Dictionary (2000). Great Britain: Chambers Harrap Publishers Ltd. Design ( $5^{\text {th }}$ edition). California: Wadsworth. edu/- mccay/apdm/selusing/selusing_d.htmEducation, Inc.

[16] Cheng, D. W., Chae, M., \& Gunn, R. W. (1998). Splitting and projective identification in multicultural group counseling. Journal for Specialists in Group Work, 23 (A), 372-387.

[17] Clarebout, G., \& Elsen, J. (2001). The ParlEuNet-project: Problems with the validation of socioconstructivist design principles in ecological settings. Computers in Human Behavior, 17 (516), 453-464.
[18] Conrad, D. L. (2002). Engagement, excitement, anxiety, and fear: Learners' experiences of starting an online course. American Journal of Distance Education, 16 (4), 205-226.

[19] Curtis, D. D., \& Lawson, M. J. (2001). Exploring collaborative online learning. Journal of Asynchronous Learning Networks, 5(1), 21-34.

[20] Dirkx, J. M., \& Smith, R. 6., (2004). Thinking out of a bowl of spaghetti: Learning to learn in online collaborative groups; In T. Roberts (Ed.), Online collaborative learning: Theory and practice (pp. 132-59). Hershey, PA: Idea Group.

[21] Do, S., \& Schallert, D. (2004). Emotions and classroom talk: Toward a model of the role of affect in students' experiences of classroom discussions. Journal of Educational Psychology, 96(4), 619-634.

[22] Fincham, R \& Rhodes, P (2005). Principles of organizational behaviour ( $\left.4^{\text {th }} e d\right)$. New York.

[23] Gibbard, G. S. (1974). Individuation, fusion, and role specialization. In G. Gibbard, J. J.

[24] Gagne, R. M., Wager, W.W., Golas, K. C. \& Keller, J. M (2005). Principles of Instructional.

[25] Gillies, Ashman \& Terwel (2007). The teacher's role in implementing cooperative learning in Irwin, Inc. Jersey: Pearson Merrill Prentice Hall.

[26] Handa, Y. (2003). A phenomenological exploration of mathematical engagement: Approaching an old metaphor anew. For the Learning of Mathematics, 23(1), 22-29.

[27] Hartmah, \& R. D. Mann (Eds.), Analysis of groups (pp. 247-265). San Francisco: Jossey-Bass.

[28] Hickey, D. T., Moore, A. L., \& Pellegrino, J. W. (2001). The motivational and academic consequences of elementary mathematics environments: Do constructivist innovations and reforms make a difference? American Educational Research Journal, 38, 611-652.

[29] Hyvönen, P. (2001). Motivation and emotion in CSCL/2:2: Regulation of motivation and emotions. Retrieved from http://knol.google.com/k/1-motivation-and-emotion-in-cscl-4\#

[30] Järvenoja, H., \& Järvelä, S. (2005). How students describe the sources of their emotional and motivational experiences during the learning process: A qualitative approach. Learning, 15, 465-480.

[31] Johnson, D. W., \& Johnson, R. T. (1991). Learning together and alone: Cooperative, competitive, and individualistic learning. Englewood Cliffs, NJ: Prentice Hall. Journal of Education and Practice.

[32] Kauchak, D \& Engen P. (2008). Introduction to Teaching: Becoming a Professional. New March 2, 2009 from http://teacherworld.com/potdale.html.

[33] Lazar, J., Jones, A., Bessiere, K., Ceaparu, I., \& Shneiderman, B. (2004). User frustration with technology in the workplace. AMCIS 2003 Proceedings. Paper 283. Retrieved from http://aisel.aisnet.org/amcis2003/283.

[34] Mandler, G. (1975). Mind and emotion. New York: Wiley.

[35] McConnell, D. (2002). Action research and distributed problembased learning in continuing professional education. DwMnce Education, 2(1), 59-83.

[36] McKnight, C. (2000). Teaching critical thinking through online discussions. Ediicause Quarterly, 4, 39-42.

[37] Moore, K.D (2009). Effective Instructional Strategies. Los Angeles: SAGE.

[38] Newcomb, T. (1962). Student peer group influence. In T. Newcomb \& E. Wilson (Eds.), The American college: A psychological and social interpretation of higher learning (pp. 481-495). New York: Wiley.

[39] O'Donnell, A. M., \& O'Kelly, J. (1994). Learning from peers: Beyond the rhetoric of positive results. Educational Psychology Review, 6, 321-349.

[40] Ohan, D. U and Ugwu, E. J (2010). Factors which Predict Performance in Secondary School on Problem Solving Abilities among Senior Secondary School Physics Students in Oxford University Press.

[41] Oliver, R., \& Omad, A. (2001). Student responses to collaborating and learning in a Web-based environment. Journal of Computer Assisted Learning, 7 (1), 34-47.

[42] Panitz, T. (2001). The case for student-centered instruction via collaborative learning paradigms.Retrieved from http://home.capecod.net/ tpanitz/tedsarticles/coopbenefits.htm. 
[43] Pastore, R. S. (2003). Creating, evaluating, and selecting instructional resources. Retrieved Physics. Advances in Applied Science Research, Vol. 1 (3), 255-258).

[44] Pekrun, R., Goetz, T., Titz, W., \& Perry, R. P. (2002). Academic emotions in students' self-regulated learning and achievement: A program of qualitative and quantitative research. Educational Psychologist, 37 (2), 91-105.

[45] Pinto, Y (2012). The efficacy of homogeneous groups in enhancing individual learning.

[46] Ragoonaden, K., \& Bordeleau, P. (2000). Collaborative learning via the Internet. Educational Technology \& Society, 3(3). Retrieved from http://ifets.ieee.org/periodical/vol_3_2000/d 11.html.

[47] Roberts, T. S. (2005). Computer-supported collaborative learning in higher education: An introduction. In T. S. Roberts (Ed.), Computer-supported collaborative learning in higher education (pp. 2-3). Hershey, PA.: Information Science Publishing.

[48] Rue, L. W \& Byars, L. L (1993). Supervision: Key link to productivity $\left(4^{\text {th }}\right.$ ed). USA: Richard D.

[49] Salomon, G., \& Globerson, T. (1989). When teams do not function the way they ought to. International Journal of Educational Research, 13, 89-99.

[50] Simple Harmonic Motion. Journal of Education and Practice www.iiste.org Vol. 4, No. 25, 2013.

[51] Schon D. (1990). Educating the reflective practitioner San Francisco: Jossey-Bass.
[52] Sierpinska, A., Bobos, G., \& Knipping, Ch. (2008). Sources of students frustration in pre-university level, prerequisite mathematics courses. Instructional Science, 36, 289-320.

[53] Smith, K. K., \& Berg, D. N. (1987). Paradoxes of group life: Understanding conflict, paralysis, and movement in group dynamics. San Francisco: New Lexington Press.

[54] Smith, R. O., \& Dirkx, J. M. (2003). Lost in familiar places: The struggle for voice and belonging in online adult learning groups. In the Proceedings of the 22nd Midwest Research to Practice Conference in Adult, Continuing, and Community Education (pp. 187-192). Columbus: Ohio State University.

[55] Trujillo, C. (1997).The application of W. R. Bion's group process construct to computer-mediated communications (CMC). Unpublished doctoral dissertation. Fielding Institute, Santa Barbara, CA.

[56] Unger, R. M. (1984). Passion: An essay on personality. New York: Free Press.

[57] Wells, L. J. (1995). The group-as-a-whole: A systemic socioanalytic perspective on interpersonal and group relations. In $\mathrm{J}$ Gillette \& M. McCollom (Eds.), Groups in context: A new perspective on group dynamics (pp. 50-85). Reading, MA: Addison-Wesley.

[58] Wheelan, S. A. (1994). Group processes: A developmental perspective. Boston: Allyn \& Bacon.

[59] Winters, S. K. (1974). Interracial dynamics in self-analytic groups. In G. Gibbard, J. J. Hartman, \& R. D.Mann (Eds.), Analysis of groups (pp. 197-219). San Francisco: Jossey-Bass. 